\title{
PERAN PEREMPUAN DALAM PEMUTUSAN MATA RANTAI COVID-19 MELALUI GERAKAN PEMBAGIAN 1 JUTA MASKER
}

\author{
Vera Iriani Abdullah ${ }^{1^{*}}$ \\ ${ }^{1}$ Jurusan Kebidanan, Poltekkes Kemenkes Sorong \\ J. Basuki Rachmat Km.11,5 Sorong-Papua Barat \\ *)Korespondensi: Verabdullah1977@gmail.com
}

Diterima 17 Oktober 2020 / Disetujui 25 Desember 2020

\begin{abstract}
ABSTRAK
Penyakit COVID-19 pertama kali diidentifikasi di Wuhan, penyebarannya bergerak dengan sangat cepat sehingga berdampak pada mortalitas, morbiditas, kondisi kesehatan mental, dan kerugian ekonomi. Pemerintah Indonesia mendeklarasikan penyakit virus corona 2019 sebagai bencana nasional pada 2 Maret 2020, yang memiliki konsekuensi besar pada sector ekonomi. Keadaan ekonomi masyarakat semakin terpengaruh sehingga akan mempengaruhi daya beli masyarakat termasuk didalamnya ketersediaan pembelian APD (Alat Pelindung Diri) sederhana yaitu masker. Penggunaan masker awalnya menjadi perdebatan di masyarakat, dimana pada awal Januari 2020 WHO belum merekomendasikan penggunaan masker secara massal untuk individu sehat. Namun berdasarkan hasil penelitian yang telah dilakukan selama masa pandemi menunjukkan bahwa kepatuhan dalam menggunakan masker sangat efektif dalam mencegah penularan Covid-19. Metode kegiatan menggunakan metode jemput bola dimana Tim turun langsung lokasi kegiatan yang sudah ditentukan. Hasil kegiatan terdistribusinya sebayak 200 buah masker kain dapat terdistribusi dengan baik kepada sasaran pada 4 lokasi. Masker kain yang dibagikan dalam kegiatan ini merupakan masker dengan 3 lapis yang terdiri dari penyerap di bagian dalam, lapisan dari bahan bukan tenunan pada bagian tengah seperti polypropylene serta bahan non-penyerap pada bagian luar. Sehingga masker kain ini sudah memenuhi standar masker yang disarankan oleh WHO, sehingga setidaknya masyarakat tidak menggunakan masker jenis scuba dan buff atau bahkan tidak menggunakan sama sekali.
\end{abstract}

Kata Kunci: covid-19, masker dan perempuan

\section{ABSTRACT}

The first COVID-19 disease on the move was identified in Wuhan, spreading so rapidly that it has an impact on mortality, morbidity, mental health conditions and economic losses. The Indonesian government declared the 2019 corona virus disease a national disaster on March 2,2020 , which poses a big risk to the economic sector. The economic situation of the community increases. So that it will affect the purchasing power of the community including the purchase of PPE (Personal Protective Equipment), namely masks. The use of masks for crew members in the community, where in early January 2020 WHO had not used masks en masse for healthy individuals. However, based on the results of research that has been carried out during the pandemic period, it shows that using a mask is very effective in preventing the transmission of Covid-19. The activity method uses the ball pick-up method 
where the team goes down directly to the predetermined location of the activity. The results of the distribution of 200 cloth masks can be distributed to targets at 4 locations. The cloth masks brought in this activity are masks with 3 layers consisting of an absorbent on the inside, a layer of non-woven material in the middle such as polypropylene and a nonabsorbent material on the outside. So that this cloth mask meets the mask standards requested by WHO, so at least it doesn't use a scuba and buff type mask or doesn't even use it at all.

Keywords : covid-19, masks and women

\section{PENDAHULUAN}

Novel coronavirus, telah menyebar ke lebih dari 125 negara di dunia yang menginfeksi lebih dari 100.000 populasi (Sohrabi et al. 2020). Pada awal Bulan Desember 2019, Penyakit coronavirus (COVID-19) pertama kali diidentifikasi di Wuhan, China. Penyebaran antar wilayah dan Negara bergerak sangat cepat melalui perjalanan udara (penerbangan), kereta api, dan bus. Pembatasan perjalanan dan menjaga jarak telah diterapkan di berbagai negara untuk menahan atau mengurangi penularan COVID-19 (Hu et al. 2020).

Pandemi ini berdampak pada mortalitas, morbiditas, kondisi kesehatan mental, dan kerugian ekonomi. Sejak dimulainya COVID-19 pada bulan Maret, dilaporkan sekitar 60 juta klaim telah diajukan untuk asuransi orang yang sudah tidak bekerja di Amerika Serikat. Terbatasnya ekonomi menyebabkan depresi sehingga berdampak pada penurunan kualitas hidup (Nordhaus 2018). Walaupun sebenarnya kualitas hidup antara wanita dan pria tidak ada perbedaan secara signifikan (Abdullah, Permadi, and Susiarno,2019)

Pemerintah Indonesia mendeklarasikan penyakit virus corona 2019 sebagai bencana nasional pada 2 Maret 2020, hal ini menyebabkan aktifitas masyarakat berubah secara dramatis. Walaupun banyak masyarakat yang menganggap pemerintah terlambat dalam menanggapi kasus ini, karena penangganannya 3 bulan setelah wabah pertama COVID-19 di Wuhan di Desember
2019 (Wu et al. 2020). Data kematian selama 1 bulan awal Pertanggal 13 Maret - 13 April 2020, data telah menunjukkan kasus terdiagnosis sebanyak 4.557 kasus dan sebanyak 399 meninggal. Data terbaru Pertanggal 2 Januari 2020 menunjukkan total kasus terkonfirmasi positif sudah sebanyak 743 ribu kasus, 611 ribu di laporkan sembuh dan 22.138 meninggal dunia (Covid-19 2020).

Selain menjadi masalah kesehatan global, COVID-19 memiliki konsekuensi besar pada ekonomi dunia, dan para ahli telah meramalkan bahwa COVID-19 akan menurunkan pertumbuhan produk domestik bruto global sebesar satu setengah persen untuk tahun 2020 (dari 2,9\% menjadi 2,4\%). Seluruh dunia sekarang menjadi komunitas global kecil, di mana setiap peristiwa besar yang terjadi di satu bagian pasti akan berdampak di seluruh dunia. Semakin lama virus akan terus menyebar, dampak terhadap ekonomi akan semakin terpengaruh sehingga akan mempengaruhi daya beli masyarakat termasuk didalamnya ketersediaan pembelian APD (Alat Pelindung Diri) sederhana yaitu masker (Gupta et al. 2020).

Penggunaan masker awalnya menjadi perdebatan di masyarakat, dimana pada awal Januari 2020 WHO belum merekomendasikan penggunaan masker secara massal untuk individu sehat. Namun berdasarkan hasil penelitian yang telah dilakukan selama masa pandemi menunjukkan bahwa kepatuhan dalam menggunakan masker sangat efektif dalam 
mencegah penularan Covid-19 walaupun sebenarnya hasil ini masih kontroversi. Alasan mekanis menutup mulut untuk mengurangi penularan melalui tetesan dan pernapasan (Cheng, Lam, and Leung 2020). Salah satu kekhawatiran dimasyarakat yaitu kurangnya pasokan masker medis yang harus tersedia untuk petugas kesehatan. Untuk meminimalkan masalah tersebut mala alternatifnya dengan menggunakan masker kain, yang dapat dengan mudah dibuat dan digunakan kembali setelah dicuci (Cheng et al. 2020).

Berbagai upaya telah dilakukan untuk membantu memutuskan mata rantai Covid19, baik melalui penyuluhan ataupun gerakan kampanye. Salah satu kampanye yang yang dilakukan sebagai bagian dari kegiatan preventif dengan pembagian masker kain kepada ibu hamil dan anak balita telah memberikan hasil yang maksimal (Abdullah and Haumahu 2020). Untuk itu maka tujuan kegiatan pengabdian masyarakat ini juga sebagai bagian dari kegiatan preventif untuk membantu masyarakat dalam pemenuhan kebutuhan APD (Alat Pelindung Diri) sederhana yaitu masker kain agar dapat digunakan secara berulang setelah dicuci.

Masyarakat juga di berikan
pemahaman yang baik agar tidak
menggunakan masker medis agar
ketersediaannya cukup untuk tenaga medis. Sasaran kegiatan di khususkan pada masyarakat dengan tingkat ekonomi menengah kebawah seperti pedagang tradisional, tukang ojek, supir taxi dan petani.

\section{METODE KEGIATAN}

Kegiatan dilakukan selama 1 minggu mulai dari tanggal 27 Agustus sampai dengan tanggal 1 September 2020, dengan melibatkan mahasiswa jurusan kebidanan. Fokus kegiatan di 3 lokasi yaitu pasar tradisional, akses jalan utama, daerah perkebunan dan pertanian. Metode yang digunakan adalah metode jemput bola, artinya bahwa Tim langsung turun ke lokasi kegiatan dan membagikan secara langsung kepada masyarakat dengan tetap mematuhi protocol kesehatan. Prosedur kegiatan dimulai dari rapat koordinasi oleh Penanggung Jawab, pembagian tim yang terdiri dari $5 \mathrm{Tim}$, persiapan dan pembagian bahan (masker) kepada masing-masing Tim dengan jumlah sebanyak 200 buah/Tim serta pelaksanaan Kegiatan. Untuk lebih jelasnya dapat di lihat pada uraian di bawah ini:

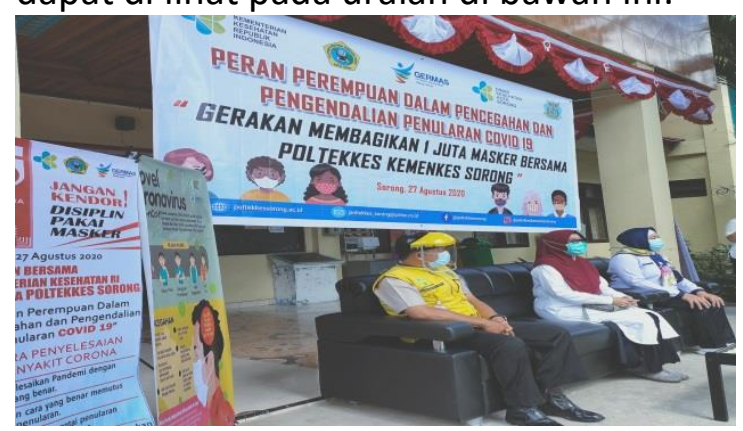

Gambar 1. Kegiatan Pembukaan (Dokumentasi Tim)

Kegiatan pembukaan dilakukan pada tanggal 27 Agustus 2020 Pukul 10.00 Wit di Poltekkes Kemenkes Sorong yang dihadiri oleh Kepala kantor Kesehatan Pelabuhan, Direktur Poltekkes Sorong Serta seluruh Tim yang terdiri dari Dosen dan mahasiswa kebidanan.

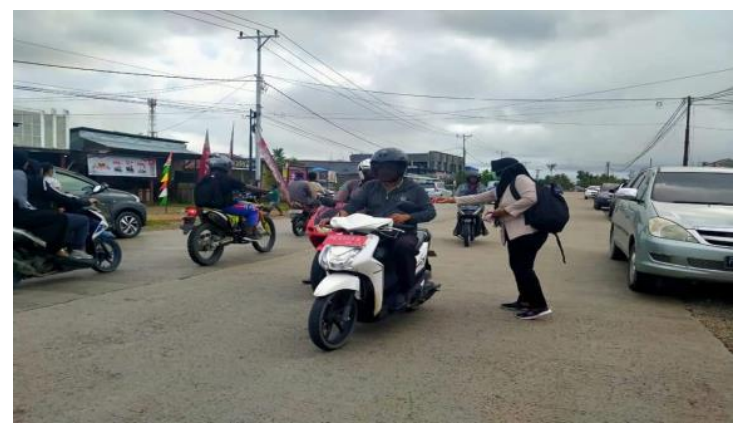

Gambar 2. Pembagian Masker Di jalan Utama (Dokumentasi Tim)

Kegiatan pembagian masker dilakukan di jalan utama pada tanggal 27 sampai dengan 28 Agustus 2020 dengan sasaran tukang ojek dan para pengguna jalan yang berada di 
lokasi kegiatan. Jumlah masker yang tersalurkan sebanyak 50 buah masker.

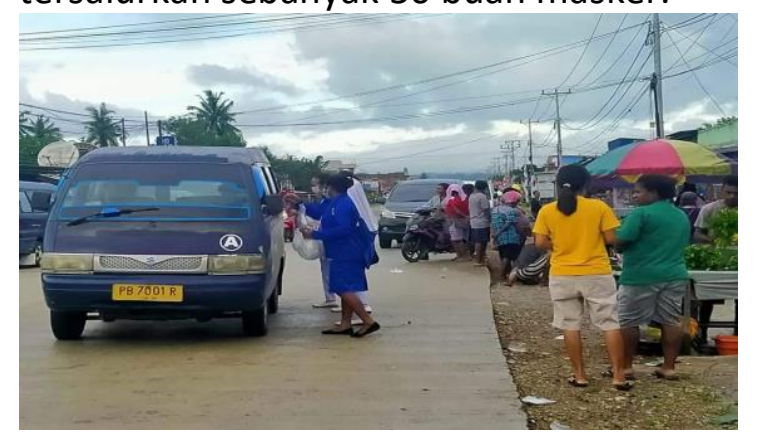

Gambar 3. Pembagian Masker Pasar

Tradisional (Dokumentasi Tim)

Kegiatan pembagian masker dilakukan di pasar tradisional pada tanggal 29 Agustus 2020 sampai dengan 30 Agustus 2020 dengan sasaran para pedagang dan pengunjung yang berada di lokasi kegiatan. Jumlah masker yang tersalurkan sebanyak 50 buah.

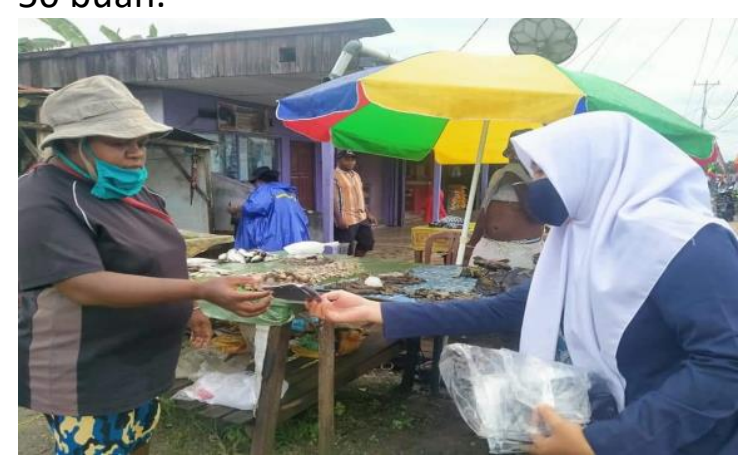

Gambar 4. Pembagian Masker Pasar

Tradisional (Dokumentasi Tim)

Kegiatan pembagian masker dilakukan di pasar tradisional pada tanggal 31 Agustus 2020 dengan sasaran para pedagang dan pengunjung yang berada di lokasi kegiatan. Jumlah masker yang tersalurkan sebanyak 50 buah.

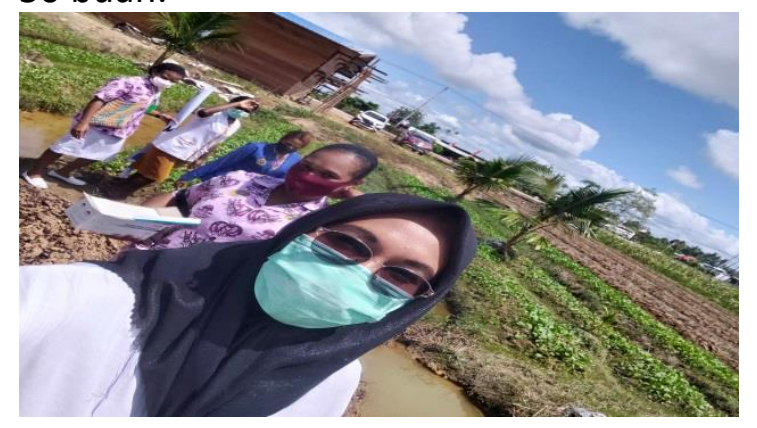

Gambar 5. Pembagian Masker Di Daerah Pertanian Dan Perkebunan (Dokumentasi Tim)

Kegiatan pembagian masker dilakukan di Pertanian Dan Perkebunan pada tanggal 01 September 2020 dengan sasaran para petani. Jumlah masker yang tersalurkan sebanyak 50 buah.

\section{HASIL DAN PEMBAHASAN}

Hasil kegiatan sesuai dengan rencana yang telah di lakukan, sebayak 200 buah masker kain dapat terdistribusi dengan baik kepada sasaran. Masyarakat sangat menyambut baik kegiatan ini karena membantu mereka dalam pemenuhan kebutuhan alat pelindung diri sederhana menggingat harga masker kain termurah sekitar Rp. 15.000/buah.

Sebuah studi literature menunjukkan bahwa dari 7 penelitian 6 diantaranya tidak merekomendasikan penggunaan masker kain dalam mencegah penularan Covid-19, namun ada 1 artikel yang menunjukkan bahwa masker kain memiliki kemampuan dalam melindungi organ pernafasan dari penularan partikel aerosol dengan menggunakan beberapa variasi kain. Walaupun penggunaan masker kain kurang efektif, namun penggunaan masker kain jauh lebih baik daripada tidak memakai masker sama sekali

( Santy Irene Putri. 2020).

Masker kain yang dibagikan dalam kegiatan ini merupakan masker dengan 3 lapis yang terdiri dari penyerap di bagian dalam, lapisan dari bahan bukan tenunan pada bagian tengah seperti polypropylene serta bahan non-penyerap pada bagian luar. Sehingga masker kain ini sudah memenuhi standar masker yang disarankan oleh WHO, sehingga setidaknya masyarakat tidak menggunakan masker jenis scuba dan buff atau bahkan tidak menggunakan sama sekali (World Health Organization 2020). 


\section{KESIMPULAN DAN SARAN \\ Kesimpulan}

Penggunakan masker menjadi salah satu alternative dalam pencegahan penularan Covid-19, dampak ekonomi sangat di rasakan oleh masyarakat ekonomi menengah kebawah sehingga sulit dalam pemenuhan APD sederhana. WHO menyarankan penggunaan masker kain 3 lapis, dengan cara penggunaan dan pencucian yang baik benar di harapkan mampu mencegah terinfeksi Covid-19. Kegiatan pengabmas ini telah menyalurkan 1 juta masker kepada sasaran dengan target 200 buah masker/ Tim. Diharapkan dengan kegiatan ini masyarakat akan mampu menjaga dirinya dan juga orang lain terhadap penyebaran Covid-19.

\section{Saran}

Pemerintah Daerah dan lembaga swadaya masyarakat kiranya dapat mengandeng Tim PKK ataupun lembaga organisasi masyarakat untuk memberikan pelatihan pembuatan masker kain sesuai standard yang dapat di distribusikan secara gratis kepada masyarakat.

\section{UCAPAN TERIMA KASIH}

Ucapan terima kasih saya sampaikan kepada Kementrian Kesehatan Republik Indonesia yang telah membantu menyiapkan 1 juta masker kain. Serta Direktur Poltekkes Sorong yang telah memberikan kesempatan kepada saya untuk terlibat secara langsung pada kegiatan ini. Mahasiswa Kebidanan Semester III Dan V yang telah membantu dalam pelaksanaan kegiatan sehingga kegiatan dapat dikerjakan sesuai rencana.

\section{DAFTAR PUSTAKA}

Abdullah, Vera Iriani, and C. H. Haumahu. 2020. "Kampanye Pemutusan Mata Rantai Penularan Corona Virus Melalui 'Gerakan Kitorang Bisa ' Pada Kelompok Resiko Tinggi." 4(2):170-74.
Abdullah, Vera Iriani, Wiryawan Permadi, and Hadi Susiarno. 2019. "Differences of Quality of Life Between Men And Women of Reproductive Age Suffering Human Immunodeficiency Virus Infection By Using The Instrument Whoqol HIV Bref IN CLINIC MAWAR BANDUNG CITY." 3(1):1-7.

Cheng, Kar Keung, Tai Hing Lam, and Chi Chiu Leung. 2020. "Wearing Face Masks in the Community during the COVID-19 Pandemic: Altruism and Solidarity." The Lancet 2019(20):2019-20.

Covid-19, Data Satgas. 2020. "No Title." Satgas Covid-19. Retrieved January 2, 2020

(https://www.google.com/search?cl ient=firefox- $b$ -

$d \& q=d a t a+$ covid+terbaru).

Gupta, Mrinal, Ayman Abdelmaksoud, Mohammad Jafferany, Torello Lotti, Roxanna Sadoughifar, and Mohamad Goldust. 2020. "COVID19 and Economy." Dermatologic Therapy 33(4):13329.

$\mathrm{Hu}$, Maogui, Hui Lin, Jinfeng Wang, Chengdong $\mathrm{Xu}$, Andrew J. Tatem, Bin Meng, Xin Zhang, Yifeng Liu, Pengda Wang, Guizhen Wu, Haiyong Xie, and Shengjie Lai. 2020. "Risk of Coronavirus Disease 2019 Transmission in Train Passengers: An Epidemiological and Modeling Study." Clinical Infectious Diseases $(X x): 1-7$.

Literatur, Studi, Efektivitas Penggunaan, Masker Kain, Program Studi, Kebidanan Program, Sarjana Terapan, Universitas Tribhuwana, and Tunggadewi Malang. 2020. "Dalam Pencegahan Transmisi Covid-19 Organisasi Kesehatan Dunia ( WHO ) Tindakan Dan Strategi Untuk Mengurangi Dampak Bergejala Yang Berada Di Rumah, 
Pengasuh , Dan Penyakit Coronavirus 2019 ( Covid-19). Pada Saat Masker Non-Medis Untuk Masyarakat Umum M." 9-17.

Nordhaus, William. 2018. "Projections and Uncertainties about Climate Change in an Era of Minimal Climate Policies." American Economic Journal: Economic Policy 10(3):33360.

Sohrabi, Catrin, Zaid Alsafi, Niamh O'Neill, Mehdi Khan, Ahmed Kerwan, Ahmed Al-Jabir, Christos losifidis, and Riaz Agha. 2020. "World Health Organization Declares Global Emergency: A Review of the 2019 Novel Coronavirus (COVID-19)." International Journal of Surgery 76(February):71-76.
World Health Organization. 2020. "WHO Updated Guidance on The Use of Masks." (30):1-14.

Wu, Aiping, Yousong Peng, Baoying Huang, Xiao Ding, Xianyue Wang, Peihua Niu, Jing Meng, Zhaozhong Zhu, Zheng Zhang, Jiangyuan Wang, Jie Sheng, Lijun Quan, Zanxian Xia, Wenjie Tan, Genhong Cheng, and Taijiao Jiang. 2020. "Genome Composition and Divergence of the Novel Coronavirus (2019-NCoV) Originating in China." Cell Host and Microbe 27(3):325-28. 